\title{
A Brief History of Citizenship
}

\author{
Derek Heater
}

Edinburgh University Press 
(C) Derek Heater, 2004

Edinburgh University Press Ltd

22 George Square, Edinburgh

Typeset in 10/12 Times New Roman

by Simon Kear, and

printed and bound in Great Britain by

CPI Antony Rowe, Eastbourne

Transferred to digital print 2008

A CIP record for this book is available from the British Library

ISBN 0748619984 (hardback)

ISBN 0748619992 (paperback)

The right of Derek Heater

to be identified as author of this work

has been asserted in accordance with

the Copyright, Designs and Patents Act 1988 